Ewa Kowalewska-Borys

Uniwersytet w Biatymstoku

Emilia Truskolaska

Uniwersytet $w$ Biatymstoku

\title{
KONWENCJA RADY EUROPY O ZAPOBIEGANIU I ZWALCZANIU PRZEMOCY WOBEC KOBIET I PRZEMOCY DOMOWEJ Z 2011 R. - ZAGADNIENIA WYBRANE
}

Konwencja Rady Europy o zapobieganiu i zwalczaniu przemocy wobec kobiet i przemocy domowej ${ }^{1}$, która została otwarta do podpisu w dniu 11 maja $2011 \mathrm{r}$. w Stambule, jest w Polsce przedmiotem wielu burzliwych dyskusji. Wzbudza wiele kontrowersji oraz krańcowo różnych opinii. Istotna wydaje się zatem analiza postanowień konwencyjnych ${ }^{2}$ oraz czytelne i całościowe przedstawienie argumentów jej zwolenników oraz oponentów. Jednakże z uwagi na ograniczone ramy opracowania omówione zostaną jedynie wybrane, acz istotne postanowienia oraz pojęcia Konwencji.

W preambule Konwencji Rady Europy o zapobieganiu i zwalczaniu przemocy wobec kobiet i przemocy domowej (tzw. Konwencji stambulskiej albo Konwencji antyprzemocowej) państwa członkowskie Rady Europy i inni sygnatariusze niniejszej konwencji zobowiązują się do poszanowania i ochrony praw człowieka i podsta-

W niniejszych rozważaniach pojęcia „przemoc domowa” oraz „przemoc w rodzinie” traktowane są synonimiczne $z$ uwagi na fakt, iż polskie tłumaczenie konwencji zawiera termin „przemoc domowa”, natomiast polska ustawa z dn. 29 lipca 2005 r. o przeciwdziałaniu przemocy w rodzinie (tj. Dz.U. z 2005 r., poz. 1493) posługuje się pojęciem „przemoc w rodzinie”. Zgodnie z art. 2 pkt 2 polskiej ustawy antyprzemocowej przemocy w rodzinie - należy przez to rozumieć jednorazowe albo powtarzające się umyślne działanie lub zaniechanie naruszające prawa lub dobra osobiste osób wymienionych w pkt 1, w szczególności narażające te osoby na niebezpieczeństwo utraty życia, zdrowia, naruszające ich godność, nietykalność cielesną, wolność, w tym seksualną, powodujące szkody na ich zdrowiu fizycznym lub psychicznym, a także wywołujące cierpienia i krzywdy moralne u osób dotkniętych przemocą.

2 Należy zwrócić uwagę, iż zarzuty dotyczące niezgodności konwencji z konstytucją opierają się głównie na językowej wykładni polskiego tłumaczenia niektórych postanowień konwencyjnych. Nie uwzględniają one wiodącej wykładni celowościowej z użytych zwrotów z tekstu autentycznego w języku angielskim i francuskim, a także pomijają raport wyjaśniający do konwencji, który stanowi istotny uzupełniający środek interpretacji jej postanowień (wersja angielska i francuska zamieszczona na oficjalnych stronach Council of Europe). Zobacz też druk sejmowy nr 2012, z dnia 10.12.2013 r., Warszawa. Projekt uchwały przedstawia przez Rząd RP sprawę ratyfikacji konwencji Rady Europy o zapobieganiu i zwalczaniu przemocy wobec kobiet i przemocy domowej z 2011 r. Podobne stanowisko wskazuje P. Czarny w Opinii prawnej w sprawie zgodności z Konstytucją RP Konwencji Rady Europy, sporządzonej 5.07.2012 r. na zlecenie Klubu Parlamentarnego Platforma Obywatelska. http://conventions.coe.int/treaty/en/treaties/html/210.htm 
wowych wolności, potępiając wszystkie formy przemocy wobec kobiet i przemocy domowej oraz uznając, że wdrożenie de jure i de facto równości kobiet i mężczyzn ma zasadnicze znaczenie dla zapobiegania przemocy wobec kobiet, a także że przemoc wobec kobiet jest przejawem nierównych stosunków władzy między kobietami a mężczyznami na przestrzeni wieków, które doprowadziły do dominacji mężczyzn nad kobietami i dyskryminacji kobiet, a także uniemożliwiły pełne usamodzielnienie kobiet.

Państwa członkowskie Rady Europy i inni sygnatariusze nawiązują też do najważniejszych międzynarodowych instrumentów prawnych, które w ramach Rady Europy i Organizacji Narodów Zjednoczonych w sposób bezpośredni odnoszą się do zakresu zastosowania niniejszej Konwencji, tj. do Konwencji o ochronie praw człowieka i podstawowych wolności oraz protokoły do niej, Europejskiej Karty Społecznej, Konwencji Rady Europy w sprawie działań przeciwko handlowi ludźmi, Konwencji Rady Europy o ochronie dzieci przed seksualnym wykorzystywaniem i niegodziwym traktowaniem w celach seksualnych, a także zaleceń Komitetu Ministrów dla państw członkowskich Rady Europy: Zalecenia Rec (2002)5 w sprawie ochrony kobiet przed przemocą, Zalecenia CM/Rec (2007)17 w sprawie standardów i mechanizmów dotyczących równości kobiet i mężczyzn, Zalecenia $\mathrm{CM} / \mathrm{Rec}$ (2010)10 w sprawie roli mężczyzn i kobiet w zapobieganiu konfliktom i ich rozwiązywaniu oraz w umacnianiu pokoju, a także innych właściwych zaleceń, do rosnącego zbioru orzecznictwa Europejskiego Trybunału Praw Człowieka, który wyznacza ważne standardy dotyczące przemocy wobec kobiet, a ponadto do Międzynarodowego Paktu Praw Obywatelskich i Politycznych (1966), Międzynarodowego Paktu Praw Gospodarczych, Społecznych i Kulturalnych (1966), Konwencji Narodów Zjednoczonych w sprawie likwidacji wszystkich form dyskryminacji kobiet (1979) i protokołu fakultatywnego do niej (1999), a także zalecenia ogólnego nr 19 Komitetu do spraw likwidacji dyskryminacji kobiet w sprawie przemocy wobec kobiet, Konwencji Narodów Zjednoczonych o prawach dziecka (1989) i Protokołów Fakultatywnych do niej (2000), Konwencji Narodów Zjednoczonych o prawach osób niepełnosprawnych (2006), a także Statutu Międzynarodowego Trybunału Karnego (2002), Konwencji genewskiej o ochronie osób cywilnych podczas wojny (1949) oraz Protokołów Dodatkowych I i II (1977). Zakres wskazanych w Konwencji międzynarodowych instrumentów prawnych jest imponujący, a zarazem wyraża jeden z najistotniejszych jej elementów, tj. uznanie, iż przemoc wobec kobiet stanowi naruszenie praw człowieka i formę dyskryminacji.

Ponadto wskazać należy, iż w negocjacjach dotyczących Konwencji stambulskiej zostały uwzględnione dodatkowo następujące zalecenia Zgromadzenia Parlamentarnego Rady Europy: zalecenie 1450 (2000) dotyczące problematyki przemocy wobec kobiet w Europie, zalecenie 1582 (2002) w sprawie przemocy domowej wobec kobiet, zalecenie 1723 (2005) w sprawie przymusowych małżeństw i małżeństw dzieci, zalecenie 1759 (2006) dotyczące współpracy parlamentów w zwal- 
czaniu przemocy domowej wobec kobiet, zalecenie 1777 (2007) w sprawie ataków na tle seksualnym związanych z ,tzw. pigułkami gwałtu”, zalecenie 1817 (2007) dotyczące współpracy parlamentów w zwalczaniu przemocy domowej wobec kobiet (analiza przejściowa kampanii), zalecenie 1847 (2008) w sprawie zwalczania przemocy wobec kobiet (początek inicjatywy w przedmiocie Konwencji Rady Europy), zalecenie 1873 (2009) w sprawie przemocy seksualnej wobec kobiet w okresie konfliktów zbrojnych, zalecenie 1868 (2009) dotyczące sposobów zwalczania naruszeń praw człowieka ze względu na płeć, w tym w szczególności w sprawach uprowadzeń kobiet i dziewcząt, zalecenie 1861 (2009) w sprawie zabójstw kobiet (kobietobójstwa - Feminizide), zalecenie 1881 (2009) w sprawie pilnej potrzeby walki z tzw. ,przestępstwami honorowymi”, zalecenie 1887 (2009) dotyczące problematyki gwałtów kobiet, w tym w szczególności gwałtu w małżeństwie, zalecenie 1891 (2009) w sprawie sytuacji imigrantek, w zakresie szczególnego ryzyka przemocą w rodzinie oraz zalecenie 1905 (2010) w sprawie dzieci, które były świadkami przemocy domowej. Dla rzetelności prowadzonych rozważań wspomnieć również należy o następujących deklaracjach politycznych, które miały istotny wpływ na kształt normatywny Konwencji stambulskiej:

1. Deklaracja i Program Działania z Piątej Europejskiej Konferencji Ministerialnej w sprawie równości kobiet i mężczyzn (Skopje, 22-23 stycznia 2003 r.) ${ }^{3}$;

2. Deklaracja i Program Działania dla Rady Europy z Trzeciego Szczytu Szefów Państw i Rządów 46 państw członkowskich Rady Europy (Warszawa, 16-17 maja 2005 r. $)^{4}$;

3. Deklaracja Komitetu Ministrów na temat urzeczywistniania zasady równości płci (12 maja 2009 r. w Madrycie) ${ }^{5}$;

4. Rezolucja nr $1 \mathrm{w}$ sprawie zapobiegania i zwalczania przemocy wobec kobiet i przemocy w rodzinie przyjęta na 29 Konferencji Ministrów Sprawiedliwości Rady Europy (Troms, Norwegia, 18-19 czerwca 2009 r.) ${ }^{6}$;

5. Plan Działania i Rezolucja w sprawie zmniejszenia rozdźwięku pomiędzy równością de iure i de facto dla osiągania prawdziwej równości płci, przyjęte na 7. Konferencji Ministrów Rady Europy dotyczącej problematyki równości pomiędzy kobietami i mężczyznami (Baku, 24-25 maja 2010 r. $)^{7}$;

6. Dokumenty IV Światowej Konferencji Kobiet z 1995 r., tj. Deklaracja Pekińska, Platforma Działania oraz sprawozdanie Komisji Ad-hoc 23 nadzwyczajnej sesji Zgromadzenia Ogólnego ONZ (Pekin+5 - deklaracja i procesie demokratycznym w krajach po zakończeniu konfliktu (2005/2215(INI)).

4 http://www.strasburgre.msz.gov.pl/pl/o_re/3_szczyt/

5 Biuro Informacji Rady Europy, „Rada Europy. Równość praw kobiet i mężczyzn w wybranych dokumentach, Warszawa 2010.

6 http://www.robert-schuman.eu/pl/biuletyn/400

http://www.coe.int/t/dc/files/ministerial_conferences/2009_justice/default_EN.asp

https://www.kongreskobiet.pl/Content/uploaded/files/sytuacja_kobiet_w_europie/rada-europy-rownosc-kobiet-i -mezczyzn-w-wybranych-dokumentach_pdf.pdf 
polityczna i wnioski) oraz polityczne deklaracje z 49. Sesji/Posiedzenia Komisji ds. Praw Kobiet ONZ (Pekin+10) z 2005 r. oraz z 54. Sesji z Posiedzenia Komisji ds. Praw Kobiet ONZ (Pekin+15), a także deklaracja „Kobiety w 2000 roku: równość płci, rozwój i pokój w XXI wieku"8.

W preambule Konwencji Rady Europy o zapobieganiu i zwalczaniu przemocy wobec kobiet i przemocy domowej z 2011 r. został wskazany główny jej cel, mianowicie stworzenie Europy bez przemocy wobec kobiet i bez przemocy domowej. W tym celu państwa członkowskie i inni sygnatariusze wskazują na ścisły związek pomiędzy dalszym urzeczywistnianiem równości kobiet i mężczyzn oraz eliminowaniem każdego rodzaju przemocy wobec kobiet. To pryncypialne określenie celu implikuje uznanie przez Umawiające się Strony strukturalnego charakteru przemocy wobec kobiet, a także stwierdzenie, że przemoc wobec kobiet jest wynikiem tradycyjnych nierówności w relacjach między kobietami i mężczyznami. W związku $\mathrm{z}$ tym już $\mathrm{w}$ preambule zostają wskazane niektóre $\mathrm{z}$ działań wymienionych $\mathrm{w}$ dalszych przepisach Konwencji, które mają, z jednej strony, eliminować zjawisko oraz przeciwdziałać zjawisku przemocy wobec kobiet, postrzeganemu w szerszym kontekście walki z dyskryminacją kobiet, zaś z drugiej strony, mają w sposób prawny i faktyczny realizować równość kobiet i mężczyzn. Należy również zauważyć, że określenie „dyskryminacja kobiet” zgodnie z art. 1 Konwencji musi być interpretowane jako „każde motywowane płcią rozróżnienie, wykluczenie lub ograniczenie, których skutkiem albo celem jest naruszenie lub udaremnienie, opartych na równouprawnieniu kobiet i mężczyzn, poszanowaniu, wykonywaniu i korzystaniu z praw człowieka i podstawowych wolności przez kobiety - niezależnie od ich stanu cywilnego - w przestrzeni politycznej, ekonomicznej, socjalnej, kulturalnej, obywatelskiej oraz każdej innej." Jednocześnie twórcy Konwencji podkreślają, że przemoc wobec kobiet oraz przemoc w rodzinie może być rozumiana, wyjaśniana i interpretowana na różne sposoby. Zatem komunikację w przedmiocie przemocy wobec kobiet i przemocy domowej należy odnosić do poziomu określonych struktur społecznych, grup albo też pojedynczych ludzi. Przemoc wobec kobiet i przemoc w rodzinie są zjawiskami złożonymi (fenomenami), które do ich zrozumienia wymagają różnych metod i instrumentów badawczych. $Z$ uwagi na fakt, że przemoc wobec kobiet stanowi zagrożenie, a nawet niemożność korzystania z przysługujących kobietom praw człowieka i wolności obywatelskich, w szczególności takich fundamentalnych praw, jak: prawo do życia, zdrowia, nietykalności cielesnej, godności oraz integralności fizycznej i psychicznej, rządy państw nie mogą ignorować zjawiska przemocy wobec kobiet, ani pozostawać bierne wobec tego poważnego problemu. Co więcej, twórcy konwencji uznają, że przemoc wobec kobiet nie tylko wpływa na sytuację kobiet, ale również na społeczeństwo jako całość i w związku z tym pilne jest podjęcie nie- 
Konwencja Rady Europy o zapobieganiu i zwalczaniu przemocy wobec kobiet...

zbędnych działań. Last but not least twórcy konwencji zwrócili uwagę na fakt, że niektóre grupy kobiet, takie jak kobiety niepełnosprawne czy dziewczęta są bardziej narażone, zarówno w domu, jak i poza nim na akty przemocy, złe traktowanie, wykorzystanie, zaniedbanie lub też inne cierpienia.

Chociaż w przepisach Konwencji podkreśla się, że przemoc wobec kobiet i związana $\mathrm{z}$ nią przemoc $\mathrm{w}$ rodzinie są określane jako zjawisko/fenomen, które wiąże się $\mathrm{w}$ sposób szczególny $\mathrm{z}$ różnicami występującymi pomiędzy płciami, to jednak wyraźnie zostaje wskazane, że również mężczyźni i chłopcy mogą być ofiarami przemocy domowej i że również takiej przemocy należy zapobiegać oraz ją zwalczać. W odniesieniu zaś do dzieci, twórcy konwencji jednoznacznie uznają, że dzieci wcale nie muszą w sposób bezpośredni doświadczyć przemocy, aby zostać czy być traktowane jak jej ofiary, wystarczająca jest bowiem już sama okoliczność, że dziecko jest świadkiem przemocy, co skutkuje silnym urazem psychicznym. W omawianym kontekście niezwykle istotne jest również wskazanie, że twórcy Konwencji nie zamierzają żadnymi przepisami tej Konwencji zobowiązywać Umawiające się Strony do podjęcia środków i działań sprzecznych z treścią konstytucyjnych lub innych fundamentalnych zasad krajowych porządków prawnych. Ponadto podkreślić należy, że rozwiązania zawarte w Konwencji stambulskiej nie naruszają pozytywnych zobowiązań państw członkowskich do zapewnienia ochrony wskazanych w Konwencji praw, należących przecież do uznanych praw człowieka i podstawowych wolności.

Podczas tworzenia analizowanych rozwiązań konwencyjnych zostało wykorzystane bogate orzecznictwo Europejskiego Trybunału Praw Człowieka, które wypracowało ważne standardy w zakresie problematyki przemocy wobec kobiet, a także istotne elementy dla rozwoju wielu pozytywnych obowiązków i niezbędnych działań, aby skutecznie zapobiegać temu rodzajowi przemocy.

W art. 1 ust. 1 konwencji został określony jej cel. W ustępie 1 (a) stwierdza się, że podstawowym celem Konwencji jest ochrona kobiet przed wszelkimi formami przemocy, jak również zapobieganie oraz ściganie i eliminacja przemocy wobec kobiet i przemocy domowej. Natomiast w ustępie 1 (b) wyjaśniono, że przepisy Konwencji mają przyczynić się zarówno do likwidacji wszelkich form dyskryminacji kobiet, jak również do promowania i wspierania rzeczywistej równości kobiet i mężczyzn. Z kolei w ustępie 1 (c) wyrażona została potrzeba przyjęcia kompleksowego podejścia $\mathrm{w}$ zakresie ochrony i wsparcia ofiar przemocy wobec kobiet i przemocy domowej. Objęte zakresem działania niniejszej Konwencji przypadki przemocy mają katastrofalne skutki dla ofiar. Jest zatem niezbędne, aby stworzyć szerokie i kompleksowe rozwiązania, nie tylko w celu zapewnienia ofiarom przyszłego bezpieczeństwa oraz przywrócenia im fizycznego i emocjonalnego zdrowia, ale także w celu umożliwienia im odbudowania swojego życia i aktywności. Rozwiązania konwencyjne powinny zaś być oparte na dogmatyce podstawowych praw człowieka i wolności obywatelskich. W ustępie 1 (d) poruszona została kwe- 
stia międzynarodowej współpracy, która szczegółowo opisana jest w rozdziale VIII Konwencji. Międzynarodowa współpraca nie ogranicza się jedynie do współpracy prawnej w sprawach cywilnych i karnych, ale obejmuje także wymianę informacji w zakresie zapobiegania przestępczości związanej z przemocą, jak również w zakresie zagwarantowania ochrony przed każdą bezpośrednią szkodą wynikającą z aktów przemocy. Eliminacja przemocy wymaga daleko idącej współpracy między instytucjami i urzędami w zakresie ich określonych kompetencji w ramach tzw. zintegrowanego podejścia. Przyjęcie takiego podejścia w celu zapobiegania i zwalczania wszelkich form przemocy wobec kobiet zostało wyraźnie określone w ustępie 1 (e) i stanowi ostateczny cel Konwencji stambulskiej. Szczegółowa regulacja zawarta została przede wszystkim w rozdziale II Konwencji.

W ustępie 2 art. 1 Konwencji został natomiast ustanowiony specjalny mechanizm monitorowania $\mathrm{w}$ celu zapewnienia skutecznego wprowadzania $\mathrm{w}$ życie przez Umawiające się Strony postanowień konwencyjnych. Jednakże nie chodzi tu tylko o osiągnięcie tego celu, ale również o zagwarantowanie długoterminowej skuteczności podjętych działań antyprzemocowych.

Ustęp 1 art. 2 Konwencji stambulskiej wskazuje, że rozwiązania prawne zawarte w niniejszej Konwencji mają zastosowanie do wszystkich form przemocy wobec kobiet, w tym przemocy w rodzinie. To unormowanie stanowi konsekwencję ustaleń faktycznych, że ofiarami przemocy są w przeważającej większości kobiety9.

Postanowienie ust. 2 art. 2 inspiruje Umawiające się Strony do rozszerzenia zakresu stosowania niniejszej Konwencji również w sprawach każdej przemocy, w tym przemocy w rodzinie wobec mężczyzn i dzieci. Sygnatariusze Konwencji zachowują więc swobodę wyboru w zakresie rozszerzenia zakresu działania Konwencji do tych dwóch grup ofiar. Oznacza ona również wybór najbardziej odpowiednich instrumentów prawnych, przy uwzględnieniu specyfiki tzw. kontekstu krajowego i ewolucyjnego rozwoju społeczności danego kraju. Należy podkreślić, że przepis ust. 2 art. 2 zd. 2 wskazuje, że przy stosowaniu niniejszej Konwencji Strony zobowiązane są do poświęcenia szczególnej uwagi kobietom będącym ofiarami różnych form przemocy uwarunkowanej płcią. Oznacza to, że przemoc wobec kobiet, w tym przemoc w rodzinie, musi być w centrum wszystkich działań podejmowanych w zakresie stosowania Konwencji.

Stosownie zaś do przepisu art. 2 ust. 3 niniejszą Konwencję stosuje się w czasie pokoju i w trakcie konfliktów zbrojnych. Postanowienie to jest niezwykle istotne, a zarazem stanowi konsekwencję deklaracji zawartych w preambule Konwencji. Podstawowe zasady międzynarodowego prawa humanitarnego i Rzymskiego Statutu 11.10.2013r.) http://statystyka.policja.pl/st/informacje/91165,Przeciwko-przemocy-domowej-dane-za-polrocze-20 13.html „Niebieska Karta-2013”, (data publikacji: 24.01.2014) http://www.statystyka.policja.pl/st/informacje/94596 ,quotNiebieska-Kartaquot-2013.html A. Bojkowska, Problematyka przemocy w rodzinie. Podstawowe środki prawne ochrony osób pokrzywdzonych, E. Kowalewska-Borys (red.), Warszawa 2012, s. 70 i inne; 
Konwencja Rady Europy o zapobieganiu i zwalczaniu przemocy wobec kobiet...

Międzynarodowego Trybunału Karnego, do których odnosi się preambuła Konwencji, potwierdzają indywidualną odpowiedzialność karną na podstawie prawa międzynarodowego za najpoważniejsze przestępstwa popełnione przede wszystkim, ale nie tylko podczas konfliktów zbrojnych. Artykuł 7 Statutu Rzymskiego (w sprawach o zbrodnie przeciwko ludzkości, ludobójstwo, zbrodnie wojenne, zbrodnie agresji popełnione w ramach rozległego lub systematycznego świadomego ataku skierowanego przeciwko ludności cywilnej) i art. 8 (dot. zbrodni wojennych) normują przestępstwa popełnione przeciwko kobietom, takie jak na przykład zgwałcenie, niewolnictwo seksualne, przymusowa prostytucja, wymuszona ciąża w rozumieniu art. 7 ust. 2 (f), przymusowa sterylizacja oraz inne formy przemocy seksualnej, stanowiące również poważne naruszenie Konwencji Genewskich. Niestety wciąż w czasie konfliktów zbrojnych oraz okupacji dochodzi do aktów przemocy wobec kobiet na tle seksualnym, które objęte są zakresem działania Rzymskiego Statutu Międzynarodowego Trybunału Karnego. Dlatego też wskazany przepis art. 2 ust. 3 Konwencji stambulskiej, zgodnie z zasadami międzynarodowego prawa humanitarnego i międzynarodowego prawa karnego normuje prawną możliwość długotrwałego stosowania Konwencji, zatem również w przypadkach konfliktów zbrojnych.

Dla pełnego zrozumienia postanowień niniejszej Konwencji istotne są legalne definicje pojęć, które zostały zawarte w przepisie art. 3 Konwencji:
a. ,przemoc wobec kobiet”,
b. ,przemoc w rodzinie”,
c. ,płeć społeczno-kulturowa",
d. ,przemoc wobec kobiet ze względu na płeć”,
e. ,ofiara”,
f. ,kobiety”.

Zgodnie z art. 3 pkt a Konwencji pod pojęciem ,przemoc wobec kobiet” rozumie się naruszenie praw człowieka i formę dyskryminacji kobiet i oznacza ono wszelkie akty przemocy ze względu na płeć, które powodują lub mogą prowadzić do fizycznej, seksualnej, psychologicznej lub ekonomicznej szkody lub cierpienia kobiet, w tym również groźby takich aktów, przymus lub arbitralne pozbawianie wolności, zarówno w życiu publicznym, jak i prywatnym. Należy zauważyć, że twórcy Konwencji określenie „przemoc wobec kobiet” bardzo wyraźnie definiują jako naruszenie praw człowieka i formę dyskryminacji kobiet. Takie rozumienie „przemocy wobec kobiet” ściśle związane jest z celem określonym w przepisie art. 1 (b) Konwencji. Druga część tej definicji natomiast zawiera sformułowania unormowane w Rekomendacji Rec (2002) 5 Komitetu Ministrów dla państw członkowskich w sprawie ochrony kobiet przed przemocą, a także w tekście Ogólnych Zaleceń nr 19 Komitetu ds. Likwidacji Dyskryminacji wobec Kobiet w kwestii przemocy wobec kobiet (1992) i art. 1 Deklaracji ONZ w sprawie likwidacji wszelkich form przemocy wobec kobiet. Natomiast nowym elementem jest uzupełnienie rozumienia 
„przemocy wobec kobiet” o pojęcie „szkody ekonomicznej”, która wiąże się w części przypadków z przemocą psychiczną.

Zgodnie z art. 3 pkt b Konwencji pojęcie ,przemoc domowa” oznacza wszelkie akty przemocy fizycznej, seksualnej, psychologicznej lub ekonomicznej zdarzające się w rodzinie lub gospodarstwie domowym, albo między byłymi, lub obecnymi małżonkami, lub partnerami, niezależnie od tego, czy sprawca i ofiara dzielą miejsce zamieszkania, czy nie. Ustawowa definicja przemocy domowej obejmuje też wszystkie formy przemocy, które występują w rodzinie albo w gospodarstwie domowym, nawet niezależnie od biologicznych lub prawnie uznanych więzi rodzinnych. Należy również zauważyć, iż przemoc w rodzinie obejmuje głównie dwa rodzaje przemocy: przemoc między małżonkami lub partnerami pozostającymi w związku faktycznym, przy czym dotyczy to zarówno związków istniejących lub przeszłych oraz przemoc pokoleniową, która występuje zwykle pomiędzy rodzicami i dziećmi, wstępnymi i zstępnymi. Konwencyjna definicja ,przemocy domowej” obejmuje w równym stopniu obie płcie, niezależnie od faktu, kto jest sprawcą i ofiarą przemocy.

Przemoc w rodzinie, do której dochodzi w związku, pomiędzy małżonkami czy partnerami, obecnymi lub przeszłymi, w sposób nieproporcjonalnie większy dotyczy kobiet i wyraźnie wiąże się z podziałem płci. Należy również wskazać, iż określenie „domowa”, które odnosi się przede wszystkim do najbliższego środowiska, w którym dochodzi do przemocy, może być również interpretowane jako ograniczające zakres stosowania, jednakże twórcy Konwencji podkreślają, że przemoc często trwa nadal, nawet po zakończeniu związku oraz, że warunkiem koniecznym przemocy w rodzinie wcale nie jest wspólne mieszkanie sprawcy i ofiary. Z kolei międzypokoleniowa przemoc $w$ rodzinie dotyczy przemocy istniejącej pomiędzy rodzicem a dzieckiem (zstępnym), ale również przemocy pomiędzy dwoma lub większą liczbą członków rodziny z różnych pokoleń. Również w przypadku przemocy międzypokoleniowej nie jest niezbędne wspólne mieszkanie sprawcy i ofiary, będących członkami rodziny.

Stosownie do przepisu art. 3 pkt c Konwencji pojęcie „płeć społeczno-kulturowa" oznacza społecznie skonstruowane role, zachowania, działania i atrybuty, które dane społeczeństwo uznaje za odpowiednie dla kobiet lub mężczyzn. Pojęcie to, powszechnie funkcjonujące pod nazwą „,gender”, budzi najwięcej kontrowersji.

Biorąc pod uwagę fakt, że Konwencja stambulska zobowiązuje sygnatariuszy do zapobiegania i zwalczania przemocy wobec kobiet, definiowanej w szerszym kontekście jako urzeczywistnianie równości kobiet i mężczyzn, niezbędnym jest zdefiniowanie terminu ,płci społeczno-kulturowej”, czyli „gender”. W rozumieniu niniejszej konwencji określenie ,gender” oparte jest na obu rodzajach płci - męskiej i żeńskiej - i tym samym wyraża istnienie społecznie ukształtowanych ról, sposobów zachowań, modeli postępowania oraz cech charakterystycznych, które uznane są za właściwe dla kobiet i mężczyzn dla danego społeczeństwa. Badania naukowe wykazały, że pewne role i stereotypy przyczyniają się i mnożą szkodliwe i zupełnie 
niepotrzebne zachowania, a nawet umożliwiają przyjęcie aktów przemocy wobec kobiet za dopuszczalne. Zatem w celu zmiany określonych stereotypowo przypisanych ról mężczyzn i kobiet, przyjęto w art. 12 ust. 1 Konwencji rozwiązania mające na celu eliminację uprzedzeń, określonych zwyczajów, tradycji i innych praktyk, które są oparte na założeniu niższości i podległości kobiet lub na stereotypowym podziale ról płciowych, rozumianych jako ogólne zobowiązanie do zapobiegania przemocy wobec kobiet.

W innych przepisach Konwencji wskazuje się, że zjawisko przemocy wobec kobiet i przemocy domowej należy traktować w ten sposób, żeby odpowiednio uwzględniać różnice między kobietami i mężczyznami, aby następnie odpowiednio dostosować wszelkie rodzaje i środki ochrony oraz pomocy dla ofiar przemocy. Zdaniem twórców Konwencji oznacza to, że wszelkie formy przemocy muszą być rozpatrywane w powiązaniu ze zjawiskiem ciągle występującej nierówności kobiet i mężczyzn, funkcjonujących stereotypów dotyczących podziału na określone role społeczne i płeć oraz zjawiskiem dyskryminacji, a to wszystko w celu prawidłowego uchwycenia złożoności zjawiska przemocy wobec kobiet. W związku z powyższym logiczną konsekwencją jest przyjęcie, iż termin ,gender” w niniejszej Konwencji nie może być synonimem występujących w przepisach Konwencji określeń „kobieta” i ,mężczyzna”.

Pojęcie ,przemoc wobec kobiet ze względu na płeć”, zdefiniowane w art. 3 pkt d Konwencji, oznacza przemoc skierowaną przeciwko kobiecie, ponieważ jest kobietą lub która dotyka kobiety w nieproporcjonalnie większym stopniu. Przemoc wobec kobiet różni się od innych form przemocy tym, iż głównym motywem tej przemocy jest żeńska płeć ofiary. Pojęcie przemocy warunkowanej płcią odnosi się do każdej szkody, jaka została wyrządzona kobiecie i przedstawia zarówno przyczynę, jak i skutek nierówności w relacjach, stosunkach władzy między mężczyznami i kobietami, które opierają się na występujących między mężczyznami i kobietami różnicach i które prowadzą do podporządkowania kobiet zarówno w życiu publicznym, jak i prywatnym. Według twórców Konwencji przemoc wobec kobiet jest głęboko zakorzeniona w strukturach, normach i wartościach społecznych i kulturowych, które kształtują społeczeństwo i często jej trwanie jest skutkiem zaprzeczeń i przemilczeń w dyskusji publicznej i nie tylko. Używane w niniejszej Konwencji wyrażenie ,przemoc wobec kobiet ze względu na płeć” stanowi synonim wyrażenia ,przemoc warunkowana płcią”, które występuje w Ogólnym Zaleceniu nr 19 Komitetu do spraw Eliminacji Dyskryminacji wobec Kobiet w kwestii przemocy wobec kobiet (1992), Deklaracji Zgromadzenia Ogólnego ONZ ds. eliminacji przemocy wobec kobiet (1993) oraz Rekomendacji Rec (2002) 5 Komitetu Ministrów Rady Europy dla państw członkowskich w sprawie ochrony kobiet przed przemocą (2002). Wyrażenie to należy więc interpretować w ścisłym związku z jego celem, tj. ochroną kobiet przed przemocą warunkowaną płcią. 
Zgodnie z art. 3 pkt e Konwencji pojęcie „ofiara” oznacza każdą osobę fizyczną, której dotyczą zachowania wymienione w punkcie a i b.

Konwencja zawiera wiele odniesień do pojęcia ofiary, dlatego też konieczna jest jej definicja. Konwencyjne pojęcie „ofiara” odnosi się zarówno do ofiar przemocy wobec kobiet, jak i ofiar przemocy w rodzinie, które są określone w artykule 3 (pkt a) lub w artykule 3 (pkt b). Oczywistym przy tym jest, iż ofiarami przemocy wobec kobiet mogą być tylko kobiety i dziewczęta, natomiast ofiarami przemocy w rodzinie mogą być również mężczyźni, kobiety i dzieci. Według innych międzynarodowych umów i traktatów dotyczących praw człowieka, pojęcie „dziecko” oznacza każdą osobę w wieku poniżej 18 lat. Pojęcie zaś „ofiara” należy rozumieć zgodnie z zakresem zastosowania niniejszej Konwencji.

Pojęcie „kobieta” zostało zdefiniowane w art. 3 pkt f Konwencji i oznacza również dziewczęta poniżej osiemnastego roku życia. $Z$ uwagi na okoliczność, iż przemoc wobec kobiet dotyczy również dziewczynek, dlatego też definicja legalna „kobiety“ obejmuje również dziewczęta poniżej 18. roku życia. Rozumienie takie jest ściśle związane z przedmiotem konwencyjnej regulacji. Konwencja stambulska stanowi porozumienie państw - stron tej Konwencji w zakresie przedsięwzięcia określonych zobowiązań, które są wiążące tylko dla jej sygnatariuszy. Ponadto podkreślić należy, iż tytułem przykładu postanowienia artykułów 3 i 4, nie tworzą nowych praw, ale wskazują istotne aspekty istniejących już praw człowieka. Wszelkie zobowiązania dla określonego obywatela mogą wynikać jedynie z ustawowych podstaw prawnych, które są zgodne z celem Konwencji stambulskiej. Stosownie do art. 4 strony Konwencji zobowiązane są do przyjęcia regulacji prawnych i innych rozwiązań, niezbędnych, by promować i chronić prawa wszystkich, zwłaszcza kobiet, do życia wolnego od przemocy w sferze publicznej i prywatnej (ust. 1) oraz potępiają wszelkie formy dyskryminacji kobiet i przyjmą, bez zwłoki, konieczne regulacje prawne lub inne rozwiązania w celu jej zapobiegania, zwłaszcza przez:

- wpisanie do krajowych konstytucji lub innych właściwych aktów prawnych zasady równości kobiet i mężczyzn oraz zapewnią praktyczne stosowanie tej zasady;

- zakazanie dyskryminacji kobiet, także poprzez ustanowienie sankcji, tam, gdzie okaże się to konieczne;

- uchylanie przepisów i praktyk dyskryminacyjnych wobec kobiety.

Wdrażanie postanowień niniejszej Konwencji przez strony, zwłaszcza rozwiązań chroniących prawa ofiar, będzie zapewnione bez jakiejkolwiek dyskryminacji ze względu na: płeć, płeć społeczno-kulturową, rasę, kolor skóry, język, religię, poglądy polityczne i inne, pochodzenie narodowe lub społeczne, przynależność do mniejszości narodowej, sytuację majątkową, urodzenie, orientację seksualną, tożsamość płciową, wiek, stan zdrowia, niepełnosprawność, stan cywilny, status uchodźcy, migranta lub inny (ust. 3). W myśl postanowień niniejszej Konwencji szczególne 
Konwencja Rady Europy o zapobieganiu i zwalczaniu przemocy wobec kobiet...

środki, niezbędne, by zapobiegać przemocy ze względu na płeć i chronić przed nią kobiety, nie są uznawane za dyskryminujące (ust. 4).

Konwencja Rady Europy o zapobieganiu i zwalczaniu przemocy wobec kobiet i przemocy domowej wzbudza wiele skrajnych emocji ${ }^{10}$. Za jej sprawą społeczeństwo polskie zostało podzielone na dwa przeciwstawne stanowiska. $Z$ jednej strony Konwencja jest traktowana jako konkretne i wyspecjalizowane narzędzie do zmian postaw i stereotypów, aby skutecznie zapobiegać i zwalczać wszelkie formy przemocy wobec kobiet, traktowanej jako naruszenie podstawowych praw człowieka i obywatela, zaś z drugiej - poprzez jej ideologiczny charakter, jako fundamentalny mechanizm zagrożenia dla tradycyjnego modelu rodziny.

Zastrzeżenia oponentów budzą deklaracje złożone już w preambule Konwencji, a dotyczące fundamentalnej kwestii równości płci. W jej postanowieniach przemoc wobec kobiet traktowana jest jako manifestacja nierównego stosunku sił między kobietami a mężczyznami na przestrzeni wieków, który doprowadził do dominacji mężczyzn i dyskryminacji kobiet, a także uniemożliwił pełną poprawę sytuacji kobiet. Przemoc wobec kobiet posiada zatem strukturalny charakter uwarunkowany przez płeć i stanowi jeden z podstawowych mechanizmów społecznych, za pomocą którego kobiety są spychane na podległą wobec mężczyzn pozycję, a dzieci są ofiarami przemocy domowej, również jako świadkowie przemocy w rodzinie ${ }^{11}$.

Z kolei środowisko ekspertów z Instytutu na rzecz Kultury Prawnej Ordo Iuris apeluje o protest wobec ratyfikacji Konwencji stambulskiej, gdyż w ich opinii zapisy Konwencji są w głównej mierze sprzeczne z art. 25 ust. 2 Konstytucji, który mówi o bezstronności światopoglądowej państwa polskiego. Podkreślają oni, że preambuła Konwencji posługuje się ,koncepcjami o wyraźnie marksistowskich inspiracjach", jak odwieczna walka płci czy strukturalna przemoc jako narzędzie dominacji mężczyzn. Ten marksistowski rodowód Konwencji zahacza o kolejny artykuł Ustawy Zasadniczej, a dokładnie przepis art. 13, który zabrania propagowania ideologii totalitarnych. Prezes Instytutu Ordo Iuris prof. A. Stępkowski podkreśla, że polska Konstytucja jasno deklaruje przywiązanie do tradycji, w co godzi Konwencja stambulska zmierzająca do wywrócenia istniejącego porządku społecznego, obarczając go winą za przemoc wobec kobiet. Według A. Stępkowskiego „konwencja uznaje zakorzeniony w tradycji ład społeczny za strukturalne źródło opresji względem kobiet, przyczynę historycznie ukształtowanych, nierównych relacji władzy między kobietami i mężczyznami." Zwraca on również uwagę na polską Ustawę Zasadniczą, która podkreśla łączność z tradycjami I i II Rzeczypospolitej, jak również „wyraża wdzięczność przeszłym pokoleniom Polaków za kulturę zakorzenioną

\footnotetext{
10 W celu rzetelności naukowej, poniżej autorki prezentują szeroki wachlarz poglądów i opinii w przedmiocie tzw. „Konwencji stambulskiej” z przestrzeni publicznej, istniejących w licznych dyskusjach i mediach.

11 http://pismozadra.pl/felietony/dziesiaty/711-konwencja-stambulska-to-trzeba-wiedziec), Virgins, Housewifes and ladies of the night: The situation of women in Poland, (w:) Europe in transition: past trends and future perspective, M. Płatek, K. Bajońćzyk, B. Błońska (red.), Warszawa 1999, s. 93-113.
} 
w chrześcijańskim dziedzictwie”. Tym samym, zdaniem A. Stępkowskiego, deklarowana w preambule tożsamość ideowa Konwencji, wyrażająca teorię „walki płci”, jest głęboko sprzeczna z aksjologią polskiej Konstytucji. Natomiast z uwagi na fakt, że Konwencja ma być korzystna jedynie dla kobiet, została zachwiana równowaga w zakresie równości wobec prawa i równości płci. Nie istnieje więc sposób, aby pogodzić takie rozwiązanie $\mathrm{z}$ art. 32 ust. 1 oraz z art. 33 Konstytucji, zgodnie z którymi wszyscy są wobec prawa równi i wszyscy mają prawo do równego traktowania przez władze publiczne. Ponadto prezes Instytutu na rzecz Kultury Prawnej Ordo Iuris wskazuje, że zapisy konwencji „w sposób nieuzasadniony faworyzują jedną grupę podmiotów (kobiety) w kontekście zjawiska przemocy, wykluczając pozostałe kategorie osób narażone i doświadczające przemocy, jak chociażby osoby starsze". Specjalne traktowanie tylko jednej z poszkodowanych grup osób oraz inne wyrażone powyżej wątpliwości wyraźnie sygnalizują, że omawiany dokument stanowi środek realizacji politycznego programu gender mainstreaming ${ }^{12}$. Zdaniem ekspertów Ordo Iuris, opinię taką potwierdza też język Konwencji oraz następujące wyrażenia: płeć kulturowo-społeczna (Art. 4 ust. 3), wzmocnienie pozycji kobiet (Art. 6, Art. 18 ust. 3), stereotypowy model roli kobiet i mężczyzn (Art. 12), niestereotypowe role przypisane płciom (Art. 14 ust. 1), kwestia płci społeczno-kulturowej w pojmowaniu przemocy (Art. 49 ust. 2). Termin ,płeć kulturowo-społeczna” (gender identity) to przykład nowo powstałego określenia politycznego. Głównym zaś celem wprowadzenia takiego nazewnictwa jest przezwyciężenie biologicznego faktu, że istnieją tylko dwie płcie oraz rozszerzenia rozumienia płci o nowe znaczenia, na przykład uwzględniające transseksualistów. Założenia politycznego programu gender mainstreaming ignorują fakt, że zaburzenia identyfikacji płciowej (Gender Identity Disorder) znajdują się na liście zaburzeń psychicznych - International Statistical Classification of Diseases and Related Health Problems registry (ICD-10 CM) i Diagnostic and Statistical Manual of Mental Disorders (DSM-IV DR) ${ }^{13}$.

Zasadniczy niepokój i ostry sprzeciw budzi również wpływ Konwencji na programy i treści edukacyjne, o czym jest mowa w przepisie art. 14, który normuje zobowiązanie Stron Konwencji do poruszania w podręcznikach zagadnienia dotyczacego niestereotypowych ról płciowych (czyli m.in. związków homoseksualnych). Należy zauważyć, iż przepis ten posługuje się pojemnym znaczeniowo językiem, a jego poszczególne fragmenty są bardzo ogólne i nieostre. Może to skutkować tym, iż stanie się on narzędziem do redefiniowania pojęć dotyczących tej problematyki i wykorzeniania tradycji opartych na tzw. stereotypowym modelu roli kobiet i mężczyzn.

\footnotetext{
12 http://www.naszdziennik.pl/wp/67951,konwencja-wbrew-konstytucji.html oraz http://www.ordoiuris.pl/analiza -konwencji-re-o-zapobieganiu-i-przeciwdzialaniu-przemocy-wobec-kobiet-i-przemocy-domowej,3203, analiza -prawna.html mocy-domowej,3203, analiza-prawna.html
} 
Konwencja o zapobieganiu przemocy wobec kobiet polaryzuje też środowisko polityczne. Politycy z ugrupowania Jarosława Gowina uznali Konwencję stambulską za szkodliwą i sprzeczną z polską Konstytucją. Według nich dokument ten zobowiązuje do walki z tzw. stereotypowymi rolami kobiet i mężczyzn, na przykład dotyczącymi macierzyństwa i małżeństwa. Jarosław Gowin jako ówczesny minister sprawiedliwości bezwzględnie sprzeciwstawił się ratyfikowaniu Konwencji uzasadniając to ślubowaniem wierności Konstytucji. Według niego Konstytucja RP jasno wskazuje w art. 18, że macierzyństwo i małżeństwo, definiowane jako związek kobiety i mężczyzny, są wartościami szczególnie chronionymi ${ }^{14}$.

Prezydium Konferencji Episkopatu Polski również określa Konwencję jako niebezpieczną ingerencją w system wychowawczy. Dnia 9 lipca 2012 roku prezydium wydało oświadczenie, stosownie do którego „Konwencja, choć poświęcona jest istotnemu problemowi przemocy wobec kobiet, zbudowana jest na ideologicznych i niezgodnych z prawdą założeniach, których w żaden sposób nie można zaakceptować. Wskazuje ona, że przemoc wobec kobiet jest systemowa, zaś jej źródłem są religia, tradycja i kultura. (...) Wprowadza definicję płci jako «społecznie skonstruowane role, zachowania i cechy, które dane społeczeństwo uznaje za właściwe dla kobiet i mężczyzn», przy czym całkowicie pomija naturalne, biologiczne różnice pomiędzy kobietą i mężczyzną i zakłada, że płeć można wybierać"15. Ponadto Biskupi wymieniają liczne zagrożenia, jakie mogą nastąpić za sprawą wejścia w życie przepisów Konwencji. Pojęcie męskości i kobiecości ma być usunięte z języka prawnego. Matka i ojciec mają zostać zastąpieni rodzicem pierwszym i rodzicem drugim. Dziecko ,genderowców“ nie rodzi się, ale jest przedmiotem produkcji. Zdaniem Kościoła nie można dopatrywać się źródeł przemocy wobec kobiet w religii, tradycji i kulturze oraz w dorobku cywilizacyjnym. Polska ma już bowiem wystarczające rozwiązania prawne, by przeciwdziałać przemocy wobec kobiet i przemocy domowej. W Konwencji nie ma zastosowanych nowych instrumentów pozwalających na walkę z przemocą, ponieważ wszystkie te rozwiązania są już obecne w prawie polskim.

Podstawowym zaś argumentem zwolenników Konwencji jest to, że stanowi ona pierwszy akt prawny na szczeblu europejskim, który całościowo traktuje sprawę przeciwdziałania i zwalczania przemocy wobec kobiet, a także przemocy domowej. Przypisane społecznie, niektóre role i zachowania kobiet i mężczyzn według badań europejskich mogą przyczyniać się do stosowania przemocy wobec kobiet. Dzięki regulacji prawnej dotyczącej określenia płci społeczno-kulturowej różnice te zostaną ujednolicone. Podkreśla to sens i istotę zdefiniowania pojęcia ,gender”.

Twórcy Konwencji podkreślają, że problem występowania przemocy wobec kobiet i przemocy domowej ma wyraźne powiązanie z płcią. Nie oznacza to,

\footnotetext{
14 http://pismozadra.pl/felietony/dziesiaty/711-konwencja-stambulska-to-trzeba-wiedziec)

15 Oświadczenie Prezydium Konferencji Episkopatu Polski, Warszawa, dnia 9 lipca 2012 r. http://episkopat.pl/dokumenty/pozostale/4401.1,Oswiadczenie_Prezydium_Konferencji_Episkopatu_Polski.html
} 
że problem mężczyzn i chłopców został pominięty w dokumencie, ponieważ art. 2 Konwencji pozostawia Państwom Stronom do uznania, w jaki sposób zechcą implikować przepisy do tych dwóch grup oraz osób starszych, w sytuacji, kiedy doświadczają przemocy domowej. Pojęcie płci społeczno-kulturowej ma za zadanie pomóc w rozwiązaniu problemów w związkach (w tym również homoseksualnych), w których występują akty przemocy.

Postanowienia Konwencji, wedle jej zwolenników, zawierają liczne przepisy mające na celu podniesienie statusu kobiet w społeczeństwie, zarówno w prawie, jak i w rzeczywistości, publicznej i prywatnej. Od konwencyjnych zobowiązań, które są prawnie wiążące, oczekuje się impulsu, który spowoduje dążenie społeczeństw do osiągnięcia równości pomiędzy kobietami i mężczyznami na poziomie krajowym. Przepisy Konwencji stambulskiej są zgodne z postanowieniami Konwencji w Sprawie Likwidacji Wszelkich Form Dyskryminacji Kobiet (tzw. CEDAW) z 1979 r., ${ }^{16}$ ponieważ można je zakwalifikować do następujących trzech głównych zobowiązań wypracowanych przez Komitet CEDAW w jego Ogólnym Zaleceniu Nr $25^{17}$. W celu przeciwdziałania przemocy wobec kobiet i podniesienia ich statusu Twórcy konwencji wprowadzili katalog nowych niezbędnych przestępstw karnych, do których zalicza się: genitalne okaleczanie kobiet, wymuszone małżeństwo, przymusową aborcję i sterylizację. W przypadku braku kryminalizacji wskazanych powyżej czynów w porządku prawnym określonego państwa Sygnatariusze Konwencji będą zobowiązani do wprowadzenia ich do swoich systemów prawnych. Ponadto Konwencja wprowadza dodatkowe środki pomocy ofiarom przemocy w uzyskaniu niezbędnego wsparcia. Do środków tych zaliczyć należy: zapewnienie oficjalnej infolinii dla ofiar przemocy, działającej 24 godziny na dobę oraz portalu z informacjami, odpowiednią liczbę schronisk i ośrodków wsparcia, przygotowanie procedur przesłuchań policyjnych chroniących przed wtórną wiktymizacją, monitorowanie, zbieranie danych na temat przestępstw z uwzględnieniem płci, prowadzenie akcji informacyjnych i szkoleń także dla chłopców i mężczyzn.

Konwencja stanowi pierwsze w historii międzynarodowe prawo jasno określające, że przemoc wobec kobiet i przemoc domowa nie może być uważana za sprawę prywatną. Państwa mają obowiązek zapobiegania przemocy, ochronę ofiar i karanie sprawców tej przemocy. W kwestii przemocy seksualnej i gwałtu, Konwencja stambulska obliguje do dostosowania ustawodawstwa do wymogów Konwencji

Wszystkie państwa członkowskie Rady Europy są stronami Konwencji CEDAW. Ratyfikując tę Konwencję państwa zobowiązały się nie tylko do niedyskryminowania kobiet, ale również do zapobiegania i potępiania dyskryminacji stosowanej przez osoby prywatne lub instytucje niepubliczne.

https://treaties.un.org/Pages/ViewDetails.aspx?src=TREATY\&mtdsg_no=IV-8\&chapter=4\&lang=en http://www.hfhrpol.waw.pl/pliki/Konwencja_w_Sprawie_Likwidacji_Wszelkich_Form_Dyskryminacji_Kobiet.pdf Paragrafy 6 i 7 Ogólnego Zalecenia Nr 25 Komitetu CEDAW do trzech centralnych obowiązków Państw-Stron Konwencji zaliczają: 1) eliminację wszelkiej bezpośredniej i pośredniej dyskryminacji kobiet przez prawo, 2) polepszenie faktycznej pozycji kobiet przez konkretne i skuteczne programy i politykę, 3) potrzebę zajęcia się relacjami płci społeczno-kulturowych i stereotypami opartymi na płci społeczno-kulturowej, które dotykają kobiety zarówno poprzez akty indywidualne, jak i przez prawo i struktury społeczne. 
w tym zakresie, na przykład poprzez uściślenie definicji gwałtu, opartej na braku zgody ofiary i bez wymogu użycia siły fizycznej przez sprawcę. Ponadto surowsza kara ma grozić sprawcy tzw. przestępstwa przemocy w rodzinie, z uwagi na szczególną traumę, jaką przestępczość ta wywołuje u ofiar, będących małżonkami, partnerami albo innymi członkami rodziny. Wicedyrektor UN Women - Lakshmi Puri uważa, iż „Konwencja Stambulska uzupełnia istniejące normy prawne i rozszerza międzynarodowe standardy rozumienia równości genderowej i poprawy sytuacji kobiet. Reprezentuje „złoty standard” i jest primus inter pares wśród instrumentów ukierunkowanych na eliminację przemocy wobec kobiet." ${ }^{18}$ Zwolennicy konwencji podkreślają, że punktem wyjścia jest założenie, że przemoc wobec kobiet jest uwarunkowana kulturowo i jest formą o podłożu „genderowym” (gender - based violence), którą popełnia się wobec kobiet, ze względu na fakt bycia kobietą. Artykuł $12 \S 1$ Konwencji wymaga od Państw - Stron promowania zmian w społecznych i kulturowych wzorcach zachowań kobiet i mężczyzn w celu wykorzenienia stereotypów, zwyczajów i uprzedzeń opartych na idei niższości kobiet. W pewnym stopniu gwarantuje to, by usprawiedliwienia kulturowe, oparte na zwyczaju, religii, tradycji czy też tzw. honorze nie stanowiły przesłanek dla akceptowania jakichkolwiek aktów przemocy wobec kobiet. $Z$ kolei art. 14 Konwencji wymaga, by programy nauczania systematycznie obejmowały, na wszystkich etapach edukacji, takie zagadnienia jak: równość kobiet i mężczyzn, niestereotypowe role społeczno-kulturowe, wzajemny szacunek, rozwiązywanie konfliktów w relacjach międzyludzkich bez uciekania się do przemocy. Taka forma edukacji ma podnieść świadomość dzieci i młodzieży, uwolnić od negatywnych uprzedzeń i stereotypów, umożliwić zmianę mentalności w celu skutecznego zwalczania uprzedzeń w kwestiach płci wśród poszczególnych członków społeczeństwa.

Zwolennicy Konwencji wskazują również na zapis art. $49 \S 2$, według którego zgodnie z podstawowymi zasadami praw człowieka oraz mając na względzie uwzględnienie kwestii płci społeczno-kulturowej w pojmowaniu przemocy, Strony zobowiązane zostają do podjęcia koniecznych środków prawnych lub innych działań w celu zapewnienia skutecznego dochodzenia oraz ścigania przestępstw określonych zgodnie z niniejszą Konwencją. Ich zdaniem, przedstawiciele określonych zawodów, w szczególności organów egzekwowania prawa i sądownictwa muszą działać, mając na względzie kwestię płci w przedmiocie przemocy wobec kobiet w celu zbliżenia się do ofiar i zrozumienia ich sytuacji, a zatem z konieczną wrażliwością i empatią niż okazując niedowierzanie czy kpinę. Z kolei w art. 50 Konwencji opisany jest obowiązek zapewnienia szybkiej i odpowiedniej reakcji organów egzekwowania prawa na wezwanie o pomoc w związku z formami przemocy objętymi Konwencją. Jego celem jest zapewnienie, że zarzuty dotyczące aktów przemocy wo- 
bec kobiet zyskają uwagę policji, na którą zasługują i spotkają się z odpowiednią i szybką reakcją.

Konwencję stambulską uznaje się za unikalną, ponieważ porusza kwestię udziału sektora prywatnego, w szczególności mediów i sektorów technologii informacyjnych i komunikacyjnych, by pracowały dla polepszenia poszanowania godności kobiet i by zaangażowały się w zapobieganie przemocy wobec kobiet, co gwarantuje art. 17. Działalność taka może przybierać różne formy, takie jak: wspieranie pracownic, które są ofiarami przemocy domowej i nękania, prowadzenie odpowiedniej polityki firmy przeciwko molestowaniu seksualnemu, uczestniczenie w rozwijaniu lokalnych, regionalnych czy krajowych polityk przeciwko przemocy albo też finansowe wspieranie służb pomagających ofiarom. Dodatkowo do Państw-Stron Konwencji został wystosowany apel o zachęcanie sektora technologii informacyjnych i komunikacyjnych (IT) oraz mediów, by przyjęły samoregulujące standardy, dystansowały się od szkodliwych stereotypów opartych na płci społeczno-kulturowej i od rozprzestrzeniania poniżających wizerunków kobiet czy wizerunków, które kojarzą przemoc i płeć. Fakt, poprzez jaki kobiety są przedstawiane w mediach i w Internecie ma duży wpływ na postawy i mentalność społeczeństwa, dlatego należy zwrócić na niego szczególną uwagę.

Zwolennicy Konwencji stambulskiej wskazują, iż zarówno cel, jak i główna idea konwencji są zgodne z zasadami, wartościami i normami Konstytucji RP. Zarzuty dotyczące jej niezgodności z Konstytucją opierają się głównie na językowej wykładni polskiego thumaczenia niektórych postanowień konwencyjnych. Nie uwzględniają one wiodącej wykładni celowościowej z użytych zwrotów z tekstu autentycznego $\mathrm{w}$ języku angielskim i francuskim, a także pomijają raport wyjaśniający do Konwencji, który stanowi istotny uzupełniający środek interpretacji jej postanowień ${ }^{19}$.

Niewątpliwie proces ratyfikacji Konwencji Rady Europy o zapobieganiu i zwalczaniu przemocy wobec kobiet i przemocy domowej z 2011 r. budzi wiele kontrowersji i skrajnych emocji. Jest to jednak bardzo ważny akt prawa międzynarodowego, o którym należy dyskutować. Nie do zaakceptowania jest natomiast język wypowiedzi, którym posługują się zarówno zwolennicy, jak i przeciwnicy Konwencji. Retoryka populistyczna jednych i drugich jest bowiem jedynym wspólnym elementem w dyskusji na temat ratyfikacji. Niestety zupełnie pomija się przy tym kwestie dotyczące funkcjonujących już w polskim systemie prawnym rozwiązań i instrumentów 
Konwencja Rady Europy o zapobieganiu i zwalczaniu przemocy wobec kobiet...

wprowadzonych przez polskiego ustawodawcę w celu zapobiegania i zwalczania zjawiska przemocy. 


\section{COUNCIL OF EUROPE CONVENTION ON PREVENTING AND COMBATING VIOLENCE AGAINST WOMEN AND DOMESTIC VIOLENCE OF 2011 - SELECTED ISSUES}

The article focuses on issues related to the Council of Europe Convention on preventing and combating violence against women and domestic violence. General purpose of this act is to protect the health and live of women. The first part provides an overview of some key terms and concepts of the Convention. The document raised many controversial emotions. This is contained in the second part of the article, which describes arguments of supporters and opponents.

Keywords: Istanbul Convention, gender, violence against women, domestic violence 